\title{
Constructing a Powerful Approach To Teaching and Learning in
} Elementary Social Studies

S. G. Grant and Bruce Vansledright. Boston: Houghton Mifflin, 2001, 304 pp. ISBN: 0-395-81121

The notion of bringing a 'powerful' approach to the teaching and learning of elementary social studies is not new. Perhaps the first meaningful articulation of this concept was prepared by the Task Force on Standards for Teaching and Learning in the Social Studies and approved by the National Council for Social Studies (NCSS) Board of Directors in the United States in 1992. The NCSS vision of powerful teaching and learning in the social studies was summarized in the statement that social studies teaching and learning are powerful when they are integrative, challenging, meaningful, values-based and active. The text being reviewed here provides a broader and deeper perspective on what constitutes powerful social studies teaching and learning. The ideas presented are based on respected philosophical positions and are driven largely by the experiences and approaches of the authors and other educational practitioners.

The authors' desire to write this book was motivated by their dissatisfaction with many of the elementary social studies methods books that they had reviewed for their courses. They felt that these books failed to capture the 'power and vibrancy' which is possible in the teaching and learning of social studies. Their expressed intention is to articulate a coherent and practical approach to teaching and learning elementary social studies. The authors hope that this book will help teachers and students realize the potential for powerful teaching and learning of social studies, which no doubt exists. This, they contend, is possible despite the problems that combine to make the social studies 'lifeless' for students. These problems, the authors say, include unmanageable and neutralized curricula, the elevation of mathematics and English over the social sciences in terms of time allocation, and the issue of standardized testing which the authors argue promotes a 'just the facts' approach.

The book is well organized with a clear structure. It has two distinct sections and 9 chapters. Part One is entitled 'The Commonplaces: A Framework for Powerful Social Studies Teaching'. With six chapters, this section constitutes two thirds of the book. Part Two is called ' Putting the Commonplaces into Action' and includes the remaining three chapters. The text is structured around the borrowed concept of the 'commonplaces of education' first espoused by noted scholar and educator Charles Schwab in the 1970s. Part One opens with an introductory chapter, which explains the commonplaces. The next five chapters look at each of the commonplaces, in turn. Part Two examines the workings of the commonplaces focusing on purposes and goals, planning and reflection, in separate chapters.

In Chapter One, 'The Commonplaces of Education: Creating a Framework for the Social Studies Classroom,' the authors present an overview of the commonplaces and the interactions between them. The commonplaces are 
identified as 'learners and learning,' 'subject matter,' 'teachers and teaching,' and 'classroom environment.' The interaction between them is shown in diagrammatic form (p.20). This chapter seeks to address three important issues the key elements of each commonplace, the interactions of the commonplaces and the ways in which an understanding of the commonplaces help teachers to think about teaching and learning. The authors use case studies from real classrooms to demonstrate how each commonplace comes into play. Several concepts that figure prominently throughout the text are introduced in this chapter. These include, 'constructivism' (p22) 'social studies threads' (p25) 'genuine classroom community' (p31) and the notion of 'big ideas' in social studies (p. 26).

Chapter Two is devoted to the first of the commonplaces - learners and learning. This chapter explores the extent of students' knowledge about social studies issues, the origins of such knowledge and the processes which they learn new ideas. A good deal of this chapter is dedicated to a discussion of constructivist views of learning. The authors discuss the fundamental tenets of constructivsm and compare these with the views of behaviorists. They also discuss their perceptions of shortcomings in constructivists' arguments. In the final analysis, constructivism is offered as the most convincing explanation of how students learn, although it is not problem free.

Chapter Three discusses the second commonplace-subject matter. Here the authors argue the wisdom of taking the 'threads' approach to the delivery of social studies content. They advocate that the integrative threads provide a conceptual framework consisting of the elements of the individual disciplines that comprise the social studies. The authors argue that the threads approach is particularly cogent in the development of teaching units and lesson plans. They suggest that this approach can help teacher candidates to bring multiple perspectives to bear in their practice.

The third commonplace - teachers and teaching - is considered important enough to have two chapters dedicated to it. In chapter Four, the principle of working with big ideas is explored. The authors address three fundamental issues in this chapter- the characteristics of big ideas, the elements that frame the development of big ideas and how the notion of a big idea fits into pedagogical action. An enduring theme throughout the chapter is that teaching is far more than just managing student behavior or utilizing a variety of teaching strategies. Chapter Five focuses on three key elements of teaching - teaching strategies, curriculum materials and assessment strategies/approaches. A wide variety of teaching strategies for individual, group and whole class instruction is discussed. The authors then examine a variety of resources and materials available to teachers and students. The discussion turns to an examination of appropriate assessment techniques before ending with an overview of the factors that influence the decisions that teachers make about classroom instruction.

Chapter Six - a discussion of the fourth commonplace, classroom environment - rounds out Part One of the volume. This chapter deals with issues clustered around the concepts of positive learning environments, and the community of learners. The authors add interest and mystique with their reference to, and 
discussion of, what they term a 'genuine classroom community.' Grant and Vansledright argue that 'traditional' classrooms reflect a 'factory model of schooling' where value is placed on quiet, efficient individual work. They argue that in genuine classrooms, emphasis is placed on ideas, inquiry and active participation. The chapter also offers insight about how genuine classroom communities can be constructed.

Part Two of the text deals with some of the fundamental topics traditionally covered in Social Studies textbooks. In Chapter Seven the purposes, goals and objectives of social studies are explored. Chapter Eight looks at unit planning in the context of the commonplaces. The authors' present examples of unit plans developed by some of their students to demonstrate the rudiments of writing effective unit plans. They also suggest a short-hand approach to writing unit plans. The authors take issue with unit plan formats that simply constitute a series of lessons and make suggestions for taking unit planning to another level.

Chapter Nine will bring joy to every teacher educator who advocates the central importance of reflective practice among teachers. The authors cap their text with a vibrant discussion of self-reflection, which they advance as the core of good teaching. The chapter discusses the importance of personal and professional growth arguing that these impact on each other. The discussion then turns to the nature of reflection and the importance of interactions between and among teachers. Reference is made to the 'egg crate' designs of schools, which they suggest hinder interaction among teachers. Teachers are called on to 'break the silence.'

The text is organized around a number of key themes and concepts, which may be identified as: the commonplaces of education, constructivist learning theory, the big ideas of social studies, the threads approach, ambitious teaching, genuine classroom community and goal-mindedness and reflection. In terms of the commonplaces, the text notes the importance of each in its own right while emphasizing their power when integrated. The rationale for the commonplaces approach by the authors can be found in the work of Joseph Schwab who argued that actions and interactions within the education process occurred in four contexts which he called the commonplaces. The philosophical framework, which informs the ideas in the book, is based on constructivist learning theory. The essence of the argument is that students are not empty vessels to be filled and our work as teaching practitioners should reflect this reality.

The 'big ideas' concept is related to the commonplace that deals with the subject matter of social studies. The authors define big ideas as 'the powerful and compelling questions and statements that run throughout the social studies' (p.6). They argue that structuring teaching around big ideas will bring powerful learning opportunities to students. The threads concept is used to demonstrate the value of an integrated approach and how this leads to powerful teaching and learning. The book illustrates how teachers can draw from several of the social science disciplines that comprise the social studies to create meaningful activities and experiences for students. The book identifies five threads - geographic, political, economic, socio-cultural and global - and uses specific examples to show how they function. The authors talk about ambitious teaching as a means of 
motivating students to embrace powerful ideas and concepts. The term ambitious is used to address expectations that students and teachers meet as they strive to bring often banal social studies teaching to life.

Grant and Vansledright argue that a special type of environment is needed for powerful social studies teaching and learning to take place. This special environment is found in genuine classroom communities. A genuine classroom community is characterized by sensitivity to the needs of students and encouragement of thoughtfulness, caring and active learning. Connected to it is the last of the major themes, goal-mindedness and reflection. The reader is invited to step back from the four commonplaces and take an introspective look at personal beliefs and teaching philosophy and how these influence what they do as teachers of social studies.

The text includes a number of unique recurring features, which are marked by special icons. These features include vibrant classroom examples, where the authors present actual examples from elementary social studies classrooms to give real life illustrations of their ideas at work. A second feature is recent research about the teaching and learning of social studies. A third feature is the inclusion of suggested teaching resources at the end of each chapter. The other special features are classroom management, teacher reflection and choosing goals.

This is a very good textbook. It is easily read at 304 pages, being both well organized and conceptually structured. The text is broken up with photographs, illustrations and graphics, making it more interesting to read. It explores many traditional social studies ideas and concepts while introducing enough innovative perspectives to make it seem new and different. Grant and Vansledright have created a very useful addition to the existing literature related to the teaching and learning of social studies.

Clinton Beckford

University of Windsor 